Е. М. Неёлов

Петрозаводск

DOI: 10.15393/j9.art.2011.332

\section{ХРИСТИАНСКАЯ ТРАДИЦИЯ \\ В РУССКОЙ ФАНТАСТИЧЕСКОЙ ЛИТЕРАТУРЕ XX - НАЧАЛА XXI ВЕКА ${ }^{1}$}

$\mathrm{X}$

ристианская традиция ${ }^{2}$ в русской франтастической литературе ${ }^{3} \mathrm{XX}$ - начала XXI века проявляется двояким образом. Во-первых, она представлена на уровне жанрового содержания произведения, во-вторых, на уровне его содержания непосредственного. Понятно, что первое существовало в фантастике всегда, а второе смогло появиться лишь в постсоветской литературе.

Обратимся сначала к первому.

(C) Неёлов Е. М., 2011

${ }^{1}$ Исследование выполнено при финансовой поддержке РГНФ в рамках научно-исследовательского проекта РГНФ «Проблемы детской литературы и журналистики: перспективы выхода из кризиса», проект № 07-04-02028a.

2 Термин «традиция» в данной статье сознательно понимается в эклектическом смысле: это и образы, и мотивы, и сюжеты, и евангельские цитаты, словом, все то, что так или иначе относится к христианскому цитать, с

${ }^{3}$ K франтастической литературе я отношу так называемую жанрово обусловленную фантастику, включающую в себя литературную сказку, научную фантастику и фюнтези. См. подробнее: Неёлов Е. М. «Жанровое содержание» научной франтастики и «рилософия общего дела» Н. Ф. Федорова // Жанр и композищия литературного произведения. Петрозаводск, 1988. С. 160-171; Он же. Еще раз о жанровой специфике фантастической литературы // Ученые записки Петрозаводского гос. университета. 2008. № 1. Июнь. С. 100-105.
Фантастическая литература генетически связана с фольклорной волшебной сказкой. В отношении литературной сказки и фэнтези это очевидно, но, как легко показывает специальный анализ, такое родство очевидно и для научной фантастики ${ }^{4}$. При этом литературная фантастика усваивает именно жанровое содержание народной волшебной сказки и многие особенности ее поэтики. А жанровое содержание волшебной сказки, как об этом я говорил в докладе на первой нашей конференции, включает в себя, если воспользоваться словами Е. Трубецкого, «чрезвычайно много сроднего христианству» ${ }^{5}$. Это «сродное христианству» связано прежде всего с учением Н. Ф. Федорова.

Натурфилософский аспект жанрового содержания волшебной сказки оказывается весьма близок «Философии общего дела». Три главные исходные федоровские идеи (родственности, регуляции, патрофикации), как выясняется, существовали в фольклорном сознании задолго до проекта Н. Федорова, представляя собой, в сущности, квинтэссенщию того, что Г. Федотов назвал «народной верой», «народной религией» ${ }^{6}$.

Таким образом, в лице Н. Федорова русская волшебная сказка обрела голос и язык, понятный городской культуре. И получается, что «русская сказка, оказывая порой пусть и незаметное, но постоянное воздействие на весь путь русской литературы, служила своеобразным каналом, по которому евангельские идеи и образы, трансформированные в духе «народной веры», проникали уже на уровне жанровых структур в мир профессионального творчества ${ }^{7}$. Особенно ярко это проявляется в франтастической литературе, где сказочность, как я уже отмечал, жанрово закреплена.

${ }^{4}$ См. подробно: Неёлов E. M. Волшебно-сказочные корни научной фантастики. Л., 1986

${ }^{5}$ Трубеикой $E$. «Иное царство» и его искатели в русской народной сказке // ЛУ. 1990. № 2. С. 144.

${ }^{6}$ Неёлов Е. М. От волшебной сказки к литературе: фрольклорная трансформация евангельской традиции в учении Н. Ф. Федорова о воскрешении // Евангельский текст в русской литературе XVIII-XX веков. Петрозаводск, 1994. С. 268. См. также: Федотов $\Gamma$. Стихи духовные (русская народная вера по духовным стихам). М., 1991.

7 Там же. С. 273. 
Федоровские идеи определяют жанровое содержание русской литературной сказки - от А. Пушкина ${ }^{8}$ до Э. Успенского (особенно в ранний период 1960-1970 годов), в научной франтастике - от А. Беляева до А. и Б. Стругацких ${ }^{9}$. В фрэнтези, в силу художественной специфики, жанровое содержание нередко напрямую соприкасается, как, например, в цикле романов М. Семеновой о Волкодаве, с непосредственным содержанием, открыто обнажая пафос, характерный для фредоровского учения (сказка рассказывает как бы саму себя). Фольклорно-сказочное жанровое содержание далеко не всегда осознается читателями, тем не менее создает своеобразную евангельскую "подсветку» всей фантастической литературе (пусть и трансформированную в духе Н. Федорова).

Если эту «подсветку» жанровых структур читатель не всегда видит, то христианские элементы в художественном содержании франтастики он замечает всегда. И сразу же встает проблема их оценки. Широко распространенную позицию, определяющую эти оценки, удачно сформулировал К. Г. Фрумкин:

Возьмем, например, Евангелие. Для христианина или историка, вставшего на позиции их предполагаемого автора, евангельские чудеса, конечно, не являются франтастикой. Для материалиста, категорически отрицающего возможность описанных в Евангелии чудес, описание превращения воды в вино является фонтастическим вымыслом ${ }^{10}$.

Такое категорическое разделение на самом деле порождает отождествление (зависящее от того, на какой позиции - христианской или атеистической - стоит исследователь). И получается, как заметил известный русский писатель-франтаст, что «серьезная франтастика, при всей приписываемой ей научности или хотя бы рациональности

${ }^{8}$ См. подробно: Неёлов E. M. О жанровом содержании «Сказки о цаpe Салтане» А. С. Пушкина // Евангельский текст в русской литературе XVIII-XX веков. Вып. 3. Петрозаводск, 2001. С. 149-162.

${ }_{9}^{9}$ См. подробно: Некрасов С. Космизм Н. Ф. Федорова и творчество Стругацких // Философия бессмертия и воскрешения. Вып. 2. М., 1996. C. $162-167$.

${ }_{10}^{10}$ Фрумкин К. Г. Философия и психология франтастики. М., 2004. C. 27. является самым религиозным видом литературы после собственно религиозной литературы» ${ }^{11}$. Другие авторы заявляют, что «вечные вопросы, объяснение основ человеческого бытия уравнивают научную франтастику с религией» ${ }^{12}$.

При этом если (условно говоря) франтастика - это тоже (или почти) религия, то возможен (с точки зрения атеиста) и обратный ход: религия - это тоже (или почти) франтастика. Собственно, так и утверждает знаменитый американский франтаст Ф. Х. Фармер: тика ${ }^{13}$.

...религия - это просто самая ранняя научная франтас-

Подобные рассуждения, реализованные на практике, создают путаницу, которая все чаще встречается в современной культуре. Так, скажем, в состав многотомной «Библиотеки русской франтастики», выходящей в 1980-1990 годы, редколлегия включает жития святых и сочинения протопопа Аввакума ${ }^{14}$, а в альбом произведений русских и зарубежных художников-франтастов попадают репродукции религиозных картин: Э. Дмитриенко «Соловецкий монастырь», О. Кандаурова «Сергий Радонежский», В. Замоги «Спас», «Русь православная» и «Георгий Победоносец» ${ }^{15}$. Тенденция к отождествлению христианских представлений с франтастическими обнаруживает себя и в серьезных научных исследованиях. А. С. Демин в своей обширной обобщающей монографии, посвященной характеристике древнерусского мировидения, даже вводит специальный раздел "Древнерусская франтастика", насчитывая в литературе Древней Руси целых девять франтастических миров, в которые опять-таки попадают и жития святых, и апокрифрические сочинения, и произведения Аввакума. В состав «древнерусской франтастики» А. С. Демин включает:

${ }^{11}$ Рыббаков В. Срочно требуется идеал // Нева. 1995. № 4. С. 160.

${ }_{12}$ Suerbaum U., Bogmeir R. Science Fiction: Theorie und Geschichte, Themen und Typen, Form und Weltbild. Stuttgard, 1981. S. 151.

${ }^{13}$ Цит. по: Гаков Вл. Мудрая ересь фантастики // Другое небо. М., 1990. C. 29.

${ }^{14}$ Библиотека русской фантастики: В 20 т. Т. 2. Звездочтец. Русская франтастика 17 века. М., 1990. С. 166-187.

${ }^{15}$ Деяния небожителей: фантастика и живопись / Сост. Ю. Медведев. Нижний Новгород, 1993. 
...чудеса, происходящие в ветхозаветные евангельские времена, а также позже в различных странах, но особенно происходящие на Руси, - явления ангелов или бесов, глас свыше, чудотворение от икон, внезапное исцеление болящих и пр. Эти сюжеты встречаются в огромном количестве памятников, их не избежало практически ни одно древнерусское произведение ${ }^{16}$.

Спорность или, скажем определеннее, ошибочность только что процитированных суждений писателей, критиков, ученых, на мой взгляд, очевидна. Евангельские чудеса даже для атеиста (в том случае, если он причастен к культурной традиции) вовсе не являются франтастикой. Ведь «рантастическое» в художественном произведении может оцениваться с позиции читателя, но может и с позиции, так сказать, онтологии текста. В первом случае «франтастическое» исторически изменчиво, ибо представления о том, что может быть на самом деле, а что не может, с ходом времени (если говорить об общественной норме) меняются. Во втором же случае обнаруживается формально-поэтическая и семантическая закрепленность франтастики в самом тексте, которая не может меняться. Чудеса в житиях святых сохраняются в своем не франтастическом, а религиозном (мифологическом в широком смысле того слова) качестве не только для современного верующего человека, но и для атеиста, обладающего развитым эстетическим сознанием, чуткого к художественной природе текста. Тот или иной образ, сюжет, мотив становятся франтастическими или недрантастическими лишь в контексте конкретного произведения (включенного, в свою очередь, в более широкие контексты - жанра, художественного направления, целой эпохи и т. д.). Так, например, мотив "глас свыше», который А. С. Демин априорно (в приведенной выше цитате) считает франтастическим, на самом деле нейтрален. В контексте древнерусской художественной эпохи и в кон-

${ }^{16}$ Делин А. С. О художественности древнерусской литературы: Очерки древнерусского мировидения от «Повести временных лет» до сочинений Аввакума. М., 1998. С. 695. Полемику с монографией А. С. Демина см. также: Неёлов E. M. Сказка и житие (статья вторая) // Еван2001. С. $64-66$. тексте агиографии он в житии святых является христианским. В контексте же современного франтастического романа (например, романа С. Снегова «Люди как боги») он, выступая, скажем, в виде неосознанного или, напротив, осознанного телепатического контакта, становится полностью фантастическим. Но сам по себе, вне контекста, этот мотив, как и другие, подобные ему, не может быть классифицирован однозначно.

Поэтому трудно согласиться с С. Лезовым, заметившим в одном из выступлений, что «вот так и у нас любители литературной мифологии Толкиена создают свои клубы, и фонкционально они не отличаются от религиозных объединений» ${ }^{17}$. Функциональную разницу между любителями толкиеновской фантастики и членами религиозных объединений определяет, на мой взгляд, принципиальное психологическое отличие. Члены фэн-клубов толкиенистов при всей своей страстной любви к фантастике, доходящей порой до «жанровой наркомании» ${ }^{18}$, все-таки играют, а в религиозных объединениях люди попадают не в игровую, а в мифологическую (в широком смысле слова, включающем и религиозное отношение к миру) реальность. Из живого мифа выйти, не разрушив его, нельзя, из игры не только можно, но и нужно.

Здесь наглядно обнаруживается главное противоречие: христианская традиция (не в культурном, но собственно религиозном качестве) требует веры, а фантастика, как фольклорная, так и литературная, всегда строится на сознательной установке на вымысел. Вера принципиально противопоказана фантастическому произведению, даже научно-франтастическому. Поэтому нет и не может быть жанра "христианской фюнтези», о котором говорят некоторые авторы в связи с творчеством, в частности, Ю. Вознесенской. Ее книги, глубоко православные по непосредственному содержанию, исполненные истинной веры, критик почему-то называет «фәнтези» ${ }^{19}$, всякую веру как раз раз-

17 Лезов С. Письмо о религии // Знамя. 1997. № 6. С. 194.

${ }^{18}$ Сапарев О. Фантастиката като литература. София, 1990. С. 36

${ }^{19}$ Павликова Е. А. Жажда истины и отваги: Послесловие // Вознесенская Ю. Путь Кассандры, или Приключение с макаронами. М., 2005. C. 569. 
рушающую. Впрочем, другой критик по поводу другого романа писательницы высказывается более осторожно:

Жанр этих книг можно обозначить как «христианское фрэнтези», но лишь условно, потому что повествуемое в них не выдумка, но символический рассказ о духовной реальности ${ }^{20}$.

В таком случае, на мой взгляд, следует просто отказаться от термина «фюнтези».

В франтастической литературе возникает парадоксальная ситуация, отсутствующая в литературе недантастической: христианская традиция на уровне непосредственного содержания оказывается в франтастике, так сказать, «во враждебной среде» и поэтому вынуждена трансдормироваться. Перед писателем, изображающим реальную действительность в формах этой самой действительности, данной проблемы не существует, перед франтастами же (в непосредственном содержании произведения) она встает весьма остро. И здесь возможны варианты.

Вариант первый, точнее «нулевой», заключается в том, что христианская традиция в произведении существует лишь на уровне содержания жанрового, никак не проявляясь на уровне непосредственного содержания. Примером, за малым исключением, может служить научная франтастика советского периода. Следующий, близкий к первому, вариант предусматривает использование писателем-франтастом христианской фрразеологии, различных христианских мотивов и образов, вошедших в культурную традицию, ставших общеизвестными, потерявших в культурном коде строгий христианский смысл, имеющих скорее светское, чем религиозное значение. Таковы, к примеру, названия романов братьев Стругацких «Трудно быть богом» и уже упоминавшегося выше С. Снегова «Люди как боги», где слово «Бог» не случайно пишется с маленькой, а не с большой буквы.

Третий вариант диаметрально противоположен двум первым. Порой авторский замысел таков, что нет необходимости в трансформации христианской традиции, ее, как

${ }^{20}$ Голосова О. Тайна смерти [Вступ. ст.] // Вознесенская Ю. Мои посмертные приключения. М., 2004. С. 15. сказал бы фоундаменталист, «недопустимом искажении». Так, в романах современного писателя-дрантаста М. Ахманова «Флибустьер» и «Ворон» (2007) современный человек проваливается в некую временную дыру и оказывается в прошлом, в начале XVIII века, и очень скоро понимает, что останется в мире прошлого навсегда. Этот мир прошлого изображен писателем без всякой франтастики, произведение, начинавшееся как фэнтези, становится по сути историческим романом (поэтому и отпадает необходимость трансформации христианской традиции). Главный герой Серов очень быстро замечает:

Люди в этом столетии сильно отличались от его современников. Не своим видом или занятиями, не повальным невежеством и даже не тем, что век их был короче лет на двадцать среди них встречались мудрецы и долгожители. Главным было различие в сфере эмоций и еще, пожалуй, в отношении к Богу. Самый отъявленный разбойник и злодей верил глубоко и искренне и либо собирался замолить свои грехи, либо бил и грабил тех, кого считал нехристями ${ }^{21}$.

Живя в этом мире, Серов (в своем времени либо атеист, либо просто человек, равнодушный к религии) постепенно меняется:

- Господь вас хранил, - молвил Серов и, неожиданно для себя самого, перекрестился. В этот миг ему казалось, что над ним, над Шейлой и всеми их людьми простерта рука Провидения, что капризная Фортуна на их стороне, что ветер Удачи будет надувать их паруса - сейчас, и присно, и вовеки веков. И понесет тот ветер их кораблям в северные моря, и будут там новые победы и приключения, новые люди и новая жизнь. Кого благодарить за это? Бога? Судьбу? Всемогущий Случай...22

Более сложная ситуация встречается в романе широко известных М. и С. Дяченко «Пандем» (2008). Писатели вводят в реалистически изображенный современный мир один единственный франтастический компонент - некую сущность, обладающую неограниченными возможностями. Эта сущность, Пандем, может принимать различные об-

${ }^{21}$ Ахманов М. Флибустьер. «Ворон». СПб., 2007. С. 17.

${ }^{22}$ Там же. С. 681. 
лики, путем уже упоминавшегося «гласа свыше» общаться с любым человеком. Пандем исполнен участия к людям, он излечивает больных, оберегает всех от различных опасностей, создает новые технологии и так далее. Но мир, оказавшийся во власти псевдобожественного существа, постепенно становится франтасмагорическим, начинается деградация человечества. И единственным островком реальности среди всей фонтасмагории оказывается церковь (потому и отпадает необходимость в трансформации христианской традиции):

Отец Георгий в последний раз перекрестился, глядя в глаза Тому, Кому привык верить и, Чьей службе посвятил жизнь. Как бы там ни было, Пандем не смел говорить с Георгием, пока Георгий говорил с Ним, не смел подавать голос во время службы, и вообще в стенах церкви молчал... ${ }^{23}$

Однако чаще всего писатели-франтасты, обращаясь к христианской традиции, создают (особенно в жанре фрэнтези) свои собственные вариации этой традиции. Это может быть своеобразная смесь христианских и языческих представлений, как в романах Ю. Никитина (цикл «Трое из Леса»), это может быть изображение франтастического мира, в котором существует религия, лишь отдаленно напоминающая христианство, это может быть авторская трансфрормация христианских представлений. $\mathcal{K}$ примеру, в романах С. Лукьяненко «Холодные берега» и «Близится утро» (2000), целиком посвященных религиозной тематике, Богочеловек, уходя из мира, который он почтил своим пребыванием, оставляет людям Слово, при помощи которого те, кто владеет им, могут творить чудеса. Сам же Спаситель тысячи лет пребывает в ледяной стране, вместо креста привязанный к столбу.

Ледяная пустыня - без конца, без края. Небо - темное, ни звезды нет, но льется тусклый серый свет. И холодно. < ..> А передо мной - столб. Деревянный столб, покрытый иголочками изморози.

И человек на нем - привязанный, прикрученный с руками за спиной, вокруг столба обвитыми, кожа льдинками ко-

${ }^{23}$ Дяченко М., Дьяченко С. Пандем. М., 2008. С. 79 лючими затянута, голова поднята - будто пытается в последний раз в небо взглянуть ${ }^{24}$.

И пока длится страдание, пока стоит святой столб, остается действенным Слово.

Можно было бы и дальше проводить все новые примеры, но сказанного уже достаточно, чтобы сорормулировать главную проблему, которую необходимо заранее решить, приступая к анализу христианской традиции в конкретном франтастическом произведении. Дело в том, что писатели-франтасты, как мы видели, обращаются с христианским материалом так же, как и с любым другим жизненным материалом, франтастически перестраивая его. Возникает вопрос, от решения которого зависит весь дальнейший анализ текста: может ли писатель-франтаст так поступать, может ли он обращаться с христианской традицией, как с любой другой традицией?

На этот вопрос у меня пока нет однозначного ответа.

\footnotetext{
${ }^{24}$ Лукьяненко С. Холодные берега. М., 2000. С. 375.
} 